\title{
A blackboard approach towards integrated Farsi OCR system
}

\author{
Hossein Khosravi • Ehsanollah Kabir
}

Published online: 29 April 2009

(c) Springer-Verlag 2009

\section{Erratum to: IJDAR}

DOI 10.1007/s10032-009-0079-7

Unfortunately for article s10032-009-0079-7 the following footnote on the first page was missing:

"This work was supported in part by Iran Telecommunication Research Center, ITRC, under contract number T-50020590."

The online version of the original article can be found under doi:10.1007/s10032-009-0079-7.

H. Khosravi $(\varangle)$ · E. Kabir

Department of Electrical Engineering,

Tarbiat Modarres University, Tehran, Iran

e-mail: HosseinKhosravi@modares.ac.ir 